Gil Gonçalves', Haitham Saeed², Mohamed E Abdelrahim², Hadeer S Harb², Yasmin M Madney², Kevin Eng ${ }^{3}$, Habib MR Karim ${ }^{4}$, Mohamad El-Khatib ${ }^{5}$, Bushra Mina ${ }^{6}$, Szymon Skoczyński ${ }^{7}$, Irena Sarc ${ }^{8}$, Vânia Caldeira ${ }^{9}$, Sara M Cabral', Bruno Cabrita ${ }^{10}$, Miguel Guia ${ }^{11}$, Jun Duan ${ }^{12}$, Igor Barjaktarevic ${ }^{3}$, Giuseppe Fiorentino ${ }^{13}$, Edoardo Piervincenzi ${ }^{14}$, Güniz Köksal ${ }^{15}$, Sibel 0 Sarin $^{16}$, Peter J Papadakos ${ }^{17}$, Benan Bayrakci ${ }^{18}$, Vijay Hadda ${ }^{19}$, Gerhard Laier-Groeneveld ${ }^{20}$, Karen EA Burns ${ }^{21}$, Raffaele Scala ${ }^{22}$, Andres C Alcaraz ${ }^{23}$, Antonio M Esquinas ${ }^{23}$

'Pulmonology Department, Centro Hospitalar e Universitário de Coimbra, Coimbra, Portugal

${ }^{2}$ Clinical Pharmacy Department, Faculty of Pharmacy, Beni-Suef University, Beni-Suef, Egypt

${ }^{3}$ Division of Pulmonary and Critical Care, Department of Medicine, David Geffen School of Medicine at UCLA, Los Angeles, United States ${ }^{4}$ Department of Anesthesiology and Critical Care, All India Institute of Medical Sciences, Raipur, Chhattisgarh, India

${ }^{5}$ Department of Anesthesiology, American University of Beirut-Medical Center, Beirut, Lebanon

${ }^{6}$ Department of Medicine, Division of Pulmonary and Critical Care Medicine, Northwell Health, Lenox Hill Hospital, New York, United States ${ }^{7}$ Department of Pulmonology, Faculty of Medical Sciences in Katowice, Medical University of Silesia, Katowice, Poland

${ }^{8}$ Noninvasive Ventilation Department, University Clinic for Pulmonary and Allergic Diseases, Golnik, Slovenia

${ }^{9}$ Pulmonology Department, Santa Marta Hospital, Lisbon, Portugal

${ }^{10}$ Pulmonology Department, Pedro Hispano Hospital, Matosinhos, Portugal

${ }^{11}$ Pulmonology Department, Hospital Professor Doutor Fernando Fonseca, Amadora, Portugal

${ }^{12}$ Department of Respiratory and Critical Care Medicine, the First Affiliated Hospital of Chongqing Medical University, Chongqing, China

${ }^{13}$ Respiratory Unit, AO Ospedali dei Colli Monaldi, Naples, Italy

${ }^{14}$ Department of Anaesthesiology and Intensive Care Medicine, Fondazione Policlinico Universitario A. Gemelli IRCCS, Rome, Italy

${ }^{15}$ Department of Anaesthesiology and Reanimation, Istanbul University Cerrahpasa Medical Faculty, Istanbul, Turkey

${ }^{16}$ Internal Medicine, Istanbul Umraniye Research Hospital, Istanbul, Turkey

${ }^{17}$ Department of Anesthesiology, University of Rochester, Rochester, United States

${ }^{18}$ Pediatric Intensive Care Department, Hacettepe University, Ankara, Turkey

${ }^{19}$ Department of Pulmonary, Critical Care \& Sleep Medicine, All India Institute of Medical Sciences, New Delhi, India

${ }^{20}$ Pneumology, Clinical and Home Ventilatory Support and Sleep, Schellstrasse, Bochum, Germany

${ }^{21}$ Interdepartmental Division of Critical Care Medicine, University of Toronto, Toronto, Canada

${ }^{22}$ Pulmonology and Respiratory Intensive Care Unit, S Donato Hospital, Arezzo, Italy

${ }^{23}$ Intensive Care and Noninvasive Ventilatory Unit, Hospital Morales Meseguer, Murcia, Spain

\title{
Non-invasive ventilation in patients with an altered level of consciousness. A clinical review and practical insights
}

\begin{abstract}
Non-invasive ventilation has gained an increasingly pivotal role in the treatment of acute hypoxemic and/or hypercapnic respiratory failure and offers multiple advantages over invasive mechanical ventilation. Some of these advantages include the preservation of airway defense mechanisms, a reduced need for sedation, and an avoidance of complications related to endotracheal intubation.

Despite its advantages, non-invasive ventilation has some contraindications that include, among them, severe encephalopathy. In this review article, the rationale, evidence, and drawbacks of the use of noninvasive ventilation in the context of hypercapnic and non-hypercapnic patients with an altered level of consciousness are analyzed.
\end{abstract}

Key words: non-invasive ventilation, altered consciousness, encephalopathy, coma

Adv Respir Med. 2020; 88: 233-244

Address for correspondence: Gil Gonçalves, Pulmonology Department, Centro Hospitalar e Universitário de Coimbra, Coimbra, Portugal; e-mail: bgilgoncalves@gmail.com DOI: $10.5603 /$ ARM.2020.0110

Received: 27.03 .2020

Copyright ( 2020 PTChP

ISSN 2451-4934 


\section{Introduction}

The utility of non-invasive ventilation (NIV) has been fully proven and well documented in several categories of patients with acute respiratory failure (ARF) [1-3]. Recent ERS/ATS and ISCCM guidelines reported a high level of evidence in favor of the use of NIV in acute acidic hypercapnic respiratory failure due to a COPD exacerbation, in acute pulmonary edema, in immunosuppressed hosts, and as a facilitating tool for transitioning from invasive ventilation to spontaneous breathing $[4,5]$.

By preventing endotracheal intubation (ETI), NIV confers many advantages over invasive mechanical ventilation (IMV). NIV is more comfortable and does not require the use of sedation in most cases [6]. It also allows patients to continue oral nutrition. The non-invasive interface allows positive pressure to be delivered while keeping the airway patent, thus preserving natural defense mechanisms. As such, NIV reduces morbidity and mortality by avoiding many complications associated with IMV including nosocomial ventilator-associated pneumonia, sepsis, and additional infectious sequelae [7].

Although NIV is an effective treatment, there are important limitations and contraindications to its use. In 2001, the International Consensus Conference on NIV [8] recommended against its use in the setting of cardiac or respiratory arrest, hemodynamic instability, unstable cardiac arrhythmias, severe encephalopathy (Glasgow coma scale $<10$ ), severe upper gastrointestinal bleeding, facial surgery or trauma, upper airway obstruction, and in patients who are at high risk for aspiration who are unable to protect their airway or to cooperate or clear respiratory secretions.

Most studies use the Glasgow coma scale (GCS) or the Kelly-Matthay score (KMS) to assess the level of consciousness. Although GCS is the tool which has been mostly used in the clinical setting, this 15-point scoring system in which a lower score corresponds to a lower level of consciousness was originally developed to assess and monitor changes in the level of consciousness after head trauma [9]. The 6-level KMS is a tool specifically designed to evaluate neurological alterations in patients ventilated in the intensive care unit (ICU) [10]. With the KMS, a higher score corresponds to a lower level of consciousness.

In this article, we reviewed the rationale, evidence, and pitfalls regarding use of NIV in hypercapnic and non-hypercapnic ARF in patients with an altered level of consciousness.

\section{Material and methods}

We performed a search in the PubMed National Library with the keywords "non-invasive ventilation", "hypercapnic", "hypoxemic", "altered consciousness", "encephalopathy", and "coma". Articles were selected according to their relevance to the topic of this review. Backward reference searching from selected articles was also performed. In addition, other articles were reviewed and included based on the authors' judgment of their relevance. Studies were limited to the English language.

\section{Rationale for NIV use in patients with hypercapnic ARF encephalopathy}

The pathophysiology of hypercapnic encephalopathy may be explained by the acidosis of cerebrospinal fluid and brain interstitial tissue. Acute respiratory acidosis has a greater impact on cerebrospinal fluid $\mathrm{pH}$ than metabolic acidosis does because $\mathrm{CO}_{2}$ crosses the blood-brain barrier easily and quickly due to its high liposolubility. Accordingly, symptoms of hypercapnic encephalopathy (i.e. cognitive defects, delirium, and coma) correlate more strongly with changes in cerebrospinal $\mathrm{pH}$ than with those in arterial $\mathrm{pH}$ and/or $\mathrm{PaCO}_{2}[11]$. Although several pulmonary and extrapulmonary factors are involved as well, it is safe to assume that by normalizing arterial $\mathrm{pH}$ by diminishing arterial $\mathrm{PaCO}_{2}$, cerebrospinal $\mathrm{pH}$ can be normalized as well.

The rationale for using NIV in hypercapnic encephalopathy is based on the reduction in $\mathrm{PaCO}_{2}$ levels and its advantages over IMV. Firstly, its efficacy on respiratory muscles, improvement in gas exchange, and in in-hospital mortality in patients with respiratory acidosis due to acute exacerbations of COPD with the use of NIV is comparable to that of IMV [11, 12].

Secondly, the absence of ETI and other invasive devices reduces the risk of ventilator-associated pneumonia [13].

Thirdly, the risk of gastric distension and aspiration is probably overestimated due to the physiological barriers of the upper (resting pressure between 60-139 $\mathrm{cm} \mathrm{H}_{2} \mathrm{O}$ ) [14] and lower sphincters (resting pressure between 14-41 cm $\mathrm{H}_{2} \mathrm{O}$ ) [15]; it is uncommon to use NIV pressures higher than $30 \mathrm{~cm} \mathrm{H}_{2} \mathrm{O}$, thus minimizing this risk.

Fourthly, NIV has an important role as a form of salvage therapy in frail patients with end-stage chronic respiratory failure and do-not-intubate orders, especially in cases of hypercapnic coma [16]. 
Finally, NIV has been shown to reduce the length of ICU and hospital stays and can lead to more effective resource utilization [17]. These important quality metrics translate into improved patient outcomes and reduced financial burden [11].

\section{Current evidence for the use of NIV in hypercapnic ARF encephalopathy}

We reviewed the published literature examining the use of NIV in patients with hypercapnic encephalopathy. Most reports showed an improvement in the GCS score within a few hours after NIV initiation (Figure 1, Table 1).

Corrado et al. [18] were the first to evaluate patients with hypercapnic coma of various etiologies treated with NIV (iron lung). In their study, the mean arterial $\mathrm{pH}$ was $7.13 \pm 0.3$ and $\mathrm{PaCO}_{2}$ was $112 \pm 21 \mathrm{~mm} \mathrm{Hg}$. Of the 150 patients analyzed, treatment was successful in $70 \%$, ranging from $0 \%$ in patients with a GCS of 3 to $85 \%$ with a GCS of 8. Five patients had aspiration complications, but all were successfully treated without intubation. Through multivariate analysis, a GCS of $\leq 6$ and age $\geq 70$ years were the only variables associated with NIV failure.

In a study by Briones et al. [19], the effectiveness of positive pressure NIV compared to IMV was assessed in two cohorts of twelve patients each with similar baseline characteristics (GCS $<8$, arterial $\mathrm{pH}<7.25$, APACHE II scores). Both groups presented to the Emergency Department with severe hypercapnia secondary to an acute exacerbation of COPD. NIV was considered successful when the following parameters were met: respiratory rate of $<24$ breaths/min, heart rate of $<90$ beats/min, improvement in consciousness level (GCS 15/15), and compensated arterial pH with adequate oxygen saturation at room air or with the use of a low percentage of inspired oxygen $\left(\mathrm{FiO}_{2}<31 \%\right)$. The authors identified a lower 30 day mortality ( $16.7 \%$ vs $33.3 \%, \mathrm{p}=0.01)$, fewer days on mechanical ventilation (3.6 \pm 1.1 vs $5.6 \pm$ $1.2, \mathrm{p}=0.006)$, and a shorter hospital stay (6.5 \pm 1.9 vs $11.1 \pm 4.7$ days, $\mathrm{p}=0.001$ ) in the NIV (vs IMV) group, but no differences in survival at 6 months ( $80 \%$ vs $71.4 \%, \mathrm{p}=0.80)$. This study noted that improvements in $\mathrm{PaCO}_{2}, \mathrm{pH}$, and GCS measured at 3 hours after NIV initiation were predictive of continued success of NIV therapy. Important differences, measured and unmeasured, may have existed between the cohorts and may in part explain the observed differences in outcomes.

Diaz et al. [20] prospectively examined patients with hypercapnic coma (GCS $\leq 8)$ secondary

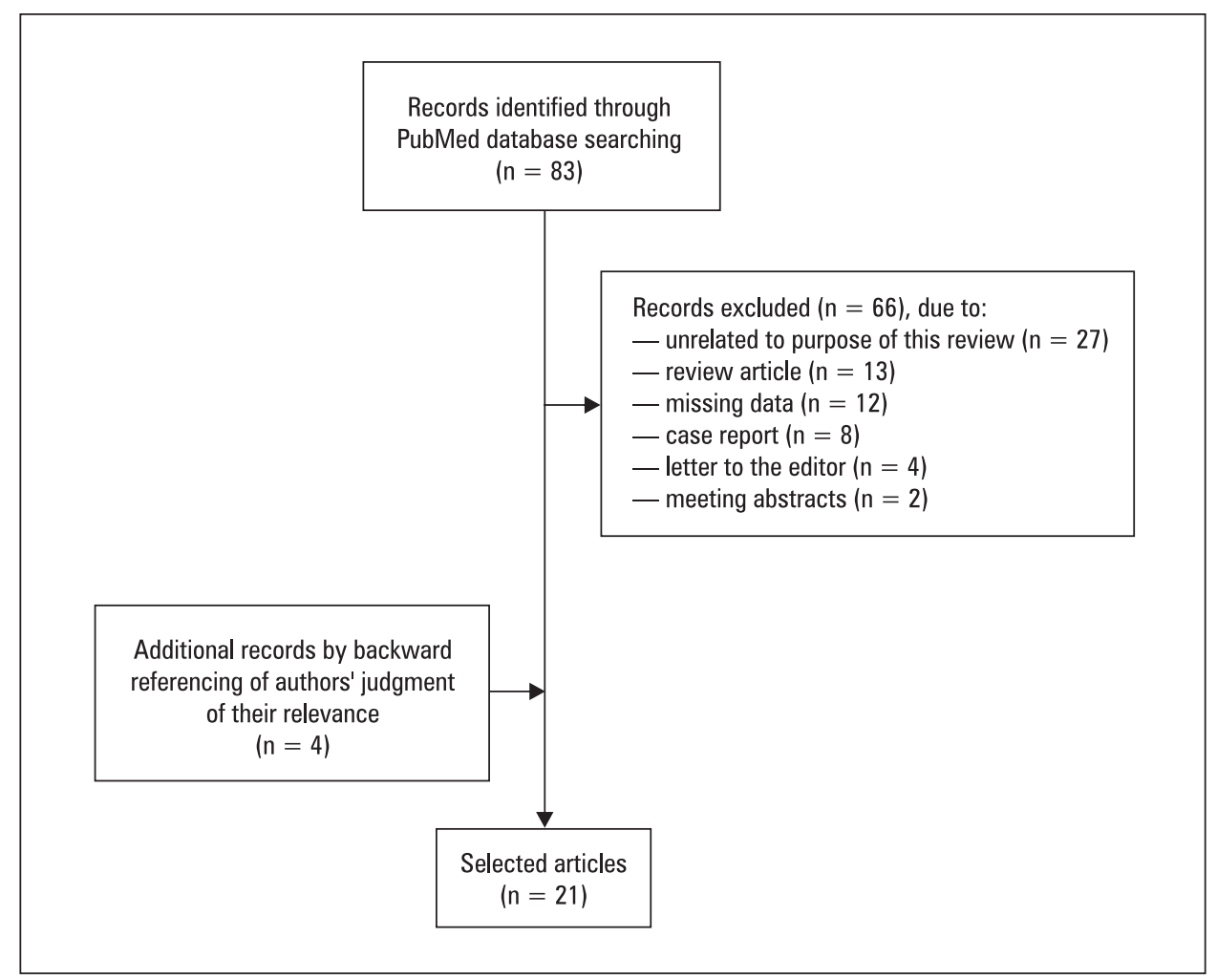

Figure 1. Flowchart of the study selection process for using non-invasive ventilation in hypercapnic acute respiratory failure encephalopathy 
Table 1. Current evidence for using NIV in hypercapnic ARF encephalopathy

\begin{tabular}{|c|c|c|c|c|c|}
\hline Author, year & $\begin{array}{l}\text { Patients and aim of } \\
\text { the study }\end{array}$ & $\begin{array}{c}\text { Level of } \\
\text { consciousness }\end{array}$ & Type of study & Results & Limitations \\
\hline $\begin{array}{l}\text { Lemyze } 2019 \\
{[16]}\end{array}$ & $\begin{array}{c}86 \text { DNI patients, NIV } \\
\text { in hypercapnic coma } \\
\text { vs NIV in hypercapnic } \\
\text { ARF without coma }\end{array}$ & $\begin{array}{c}\text { Comatose group with } \\
\text { KMS } \geq 5\end{array}$ & $\begin{array}{c}\text { Prospective observa- } \\
\text { tional case-control } \\
\text { study }\end{array}$ & $\begin{array}{l}70 \% \text { survived to } \\
\text { hospital discharge } \\
\text { and half survived } 6 \\
\text { months, with similar } \\
\text { outcomes to } \\
\text { controls }\end{array}$ & $\begin{array}{l}\text { Selection bias could } \\
\text { not be ruled out }\end{array}$ \\
\hline $\begin{array}{l}\text { Corrado } 1996 \\
\text { [18] }\end{array}$ & $\begin{array}{l}150 \text { patients, evalu- } \\
\text { ate NIV (iron lung) } \\
\text { success in } \\
\text { hypercapnic coma }\end{array}$ & All GCS 3-8 & $\begin{array}{l}\text { Retrospective, uncon- } \\
\text { trolled study }\end{array}$ & $\begin{array}{l}\text { NIV failure in } 30 \% \text {. } \\
\text { GCS } \leq 6 \\
\text { had negative prog- } \\
\text { nostic value }\end{array}$ & $\begin{array}{l}\text { Retrospective study, } \\
\text { limited availability of } \\
\text { iron lung }\end{array}$ \\
\hline $\begin{array}{l}\text { Briones } 2008 \\
{[19]}\end{array}$ & $\begin{array}{l}24 \text { patients, NIV vs } \\
\text { IMV in hypercapnic } \\
\text { coma }\end{array}$ & All GCS $<8$ & $\begin{array}{l}\text { Prospective interven- } \\
\text { tional study }\end{array}$ & $\begin{array}{l}\text { Less days on me- } \\
\text { chanical ventilation, } \\
\text { days of stay and } 30- \\
\text { day mortality }\end{array}$ & $\begin{array}{l}\text { Small group of pa- } \\
\text { tients }\end{array}$ \\
\hline Diaz 2005 [20] & $\begin{array}{c}958 \text { patients, } \\
\text { determine NIV suc- } \\
\text { cess } \\
\text { in hypercapnic coma } \\
\text { vs } \\
\text { NIV while awake }\end{array}$ & All GCS $\leq 8$ & $\begin{array}{l}\text { Prospective, open, } \\
\text { noncontrolled study }\end{array}$ & $\begin{array}{c}\text { No increase in failure } \\
\text { or mortality relative } \\
\text { to non-comatose } \\
\text { patients }\end{array}$ & $\begin{array}{l}\text { Observational design, } \\
\text { lack of control sub- } \\
\text { jects }\end{array}$ \\
\hline Scala 2007 [21] & $\begin{array}{l}40 \text { patients, NIV vs } \\
\text { IMV in hypercapnic } \\
\text { encephalopathy }\end{array}$ & All KMS $\geq 3$ & $\begin{array}{l}\text { Prospective matched } \\
\text { case-control } \\
\text { study }\end{array}$ & $\begin{array}{c}\text { Shorter duration of } \\
\text { mechanical ventila- } \\
\text { tion and lower rate of } \\
\text { complications. Mor- } \\
\text { tality similar in both } \\
\text { groups }\end{array}$ & $\begin{array}{l}\text { Case-control design } \\
\text { and lack of random- } \\
\text { ization }\end{array}$ \\
\hline Zhu 2007 [22] & $\begin{array}{c}68 \text { patients, } \\
\text { evaluate the effec- } \\
\text { tiveness and safety } \\
\text { of NIV for severe } \\
\text { hypercapnic enceph- } \\
\text { alopathy }\end{array}$ & $\begin{aligned} \text { GCS } & <10 \text { vs GCS } \\
& \geq 10\end{aligned}$ & $\begin{array}{c}\text { Prospective } \\
\text { case-control study }\end{array}$ & $\begin{array}{l}\text { Similar results in } \\
\text { hospital mortality and } \\
\text { NIV success vs con- } \\
\text { trol group }\end{array}$ & $\begin{array}{l}\text { Different levels of } \\
\text { pressure support and } \\
\text { NIV time between } \\
\text { groups }\end{array}$ \\
\hline Stefan 2015 [24] & $\begin{array}{l}2577 \text { patients, com- } \\
\text { pare outcomes of } \\
\text { acute exacerbation of } \\
\text { COPD, NIV vs IMV }\end{array}$ & $\begin{array}{l}\text { GCS in NIV group of } \\
15 \text { (IOR 14-15) }\end{array}$ & $\begin{array}{l}\text { Retrospective, mul- } \\
\text { ticenter cohort of } \\
\text { prospectively collect- } \\
\text { ed data }\end{array}$ & $\begin{array}{l}\text { Lower GCS was pre- } \\
\text { dictive of NIV failure }\end{array}$ & $\begin{array}{l}\text { Patients received } \\
\text { ventilatory support } \\
\text { for an exacerbation } \\
\text { of COPD and not nec- } \\
\text { essarily hypercapnic } \\
\text { acidotic exacerbation }\end{array}$ \\
\hline $\begin{array}{l}\text { Confalonieri } 2005 \\
\text { [25] }\end{array}$ & $\begin{array}{l}1033 \text { patients, assess } \\
\text { the risk of NIV failure } \\
\text { in acute exacerba- } \\
\text { tions of COPD }\end{array}$ & GCS $13.2 \pm 2.3$ & Prospective study & $\begin{array}{l}\text { GCS } \leq 14 \text { was pre- } \\
\text { dictive of NIV failure; } \\
\text { main factor influenc- } \\
\text { ing the outcome was } \\
\text { the } \mathrm{pH} \text { value }\end{array}$ & Absent \\
\hline Fan 2014 [26] & $\begin{array}{l}261 \text { patients, mea- } \\
\text { sure cough } \\
\text { strength and out- } \\
\text { comes in acute ex- } \\
\text { acerbations of COPD } \\
\text { on NIV }\end{array}$ & $\begin{array}{l}\text { GCS } 14.8 \pm 0.5 \text { in NIV } \\
\text { success vs GCS } 13.8 \\
\pm 2.5 \text { in NIV failure }\end{array}$ & $\begin{array}{l}\text { Prospective observa- } \\
\text { tional study }\end{array}$ & $\begin{array}{l}\text { APACHE II, semi- } \\
\text { quantitative cough } \\
\text { strength score and } \\
\text { total proteins were } \\
\text { the only predictors of } \\
\text { NIV failure }\end{array}$ & $\begin{array}{l}\text { Accuracy of cough } \\
\text { measurements } \\
\text { based on the clini- } \\
\text { cians' experience }\end{array}$ \\
\hline Wang 2017 [27] & $\begin{array}{l}164 \text { patients, com- } \\
\text { pare NIV and IMV } \\
\text { combined with a } \\
\text { non-invasive strategy } \\
\text { for clearing secre- } \\
\text { tions in hypercapnic } \\
\text { encephalopathy }\end{array}$ & All KMS $\geq 3$ & $\begin{array}{l}\text { Prospective cohort } \\
\text { study }\end{array}$ & $\begin{array}{l}2 \text { hours of NIV with } \\
\text { clearance of secre- } \\
\text { tions } \\
\text { significantly improved } \\
\text { KMS and arterial } \\
\text { blood gases. Hospital } \\
\text { mortality lower in the } \\
\text { NIV group }\end{array}$ & $\begin{array}{l}\text { Not a randomized } \\
\text { controlled trial, } \\
\text { single-center study, } \\
\text { hospital setting be- } \\
\text { tween groups } \\
\text { differed, did not } \\
\text { include an additional } \\
\text { group } \\
\text { with NIV alone }\end{array}$ \\
\hline
\end{tabular}


Table 1. Current evidence for using NIV in hypercapnic ARF encephalopathy [cont.]

\begin{tabular}{|c|c|c|c|c|c|}
\hline Scala 2010 [28] & $\begin{array}{l}30 \text { patients, early } \\
\text { fiberoptic bronchos- } \\
\text { copy during NIV vs } \\
\text { IMV-based strategy in } \\
\text { hypercapnic enceph- } \\
\text { alopathy }\end{array}$ & KMS 2-4 & $\begin{array}{l}\text { Prospective matched } \\
\text { case-control study }\end{array}$ & $\begin{array}{l}\text { Higher complication } \\
\text { rates in the } \\
\text { IMV group. } \\
\text { Similar hospital mor- } \\
\text { tality, hospital lengths } \\
\text { of stay, and duration } \\
\text { of ventilation in the } \\
\text { two groups }\end{array}$ & $\begin{array}{l}\text { NIV application with } \\
\text { the concomitant use } \\
\text { of fiberoptic bron- } \\
\text { choscopy to remove } \\
\text { secretions should be } \\
\text { reserved for centers } \\
\text { where all staff mem- } \\
\text { bers } \\
\text { have sufficient expe- } \\
\text { rience }\end{array}$ \\
\hline Contou 2013 [51] & $\begin{array}{l}242 \text { patients admit- } \\
\text { ted for } \\
\text { hypercapnic ARF, } \\
\text { assess the rate } \\
\text { of NIV failure }\end{array}$ & $\begin{array}{l}\text { Included } \\
\text { RASS }<0\end{array}$ & $\begin{array}{l}\text { Observational cohort } \\
\text { study }\end{array}$ & $\begin{array}{l}\text { Altered levels of } \\
\text { consciousness at } \\
\text { admission } \\
\text { had no influence on } \\
\text { outcome }\end{array}$ & $\begin{array}{l}\text { Retrospective, single } \\
\text { unit, longstanding } \\
\text { experience in NIV } \\
\text { practice }\end{array}$ \\
\hline $\begin{array}{l}\text { Briones } 2013 \\
\text { [52] }\end{array}$ & $\begin{array}{l}22 \text { patients, BiPAP } \\
\text { S/T vs AVAPS mode }\end{array}$ & All GCS $<10$ & $\begin{array}{l}\text { Prospective interven- } \\
\text { tional match-con- } \\
\text { trolled study }\end{array}$ & $\begin{array}{l}\text { Rapid improvement in } \\
\text { arterial blood } \\
\text { gases and GCS in } \\
\text { both groups }\end{array}$ & $\begin{array}{l}\text { Small number of } \\
\text { patients }\end{array}$ \\
\hline Scala 2005 [53] & $\begin{array}{l}153 \text { patients requiring } \\
\text { NIV divided into } 4 \\
\text { groups, according to } \\
\text { level of conscious- } \\
\text { ness }\end{array}$ & $\begin{array}{c}\text { Groups: KMS 1, KMS } \\
\text { 2, KMS } 3 \text { and KMS } \\
>3\end{array}$ & $\begin{array}{l}\text { 5-year case-control } \\
\text { study with a prospec- } \\
\text { tive data collection }\end{array}$ & $\begin{array}{l}\text { Significant improve- } \\
\text { ment in arterial blood } \\
\text { gases and KMS in all } \\
\text { groups after } 1 \text { to } 2 \\
\text { hours. NIV failure and } \\
\text { 90-day mortality sig- } \\
\text { nificantly increased } \\
\text { with worse KMS }\end{array}$ & No randomization \\
\hline Jatoi 2019 [54] & $\begin{array}{l}78 \text { patients, predict } \\
\text { NIV success in post- } \\
\text { TB sequelae }\end{array}$ & $\begin{array}{l}\text { GCS } 8.4 \pm 2.1 \text { in } \\
\text { nonresponders } v s \\
\text { GCS } 9.4 \pm 1.8 \text { in } \\
\text { responders }\end{array}$ & $\begin{array}{l}\text { Single center, pro- } \\
\text { spective, cohort } \\
\text { study }\end{array}$ & $\begin{array}{l}\text { Lower GCS was a } \\
\text { significant indepen- } \\
\text { dent predictor of } \\
\text { NIV failure }\end{array}$ & $\begin{array}{l}\text { Single unit, no IMV } \\
\text { group control, ab- } \\
\text { sence of long-term } \\
\text { mortality or morbidity }\end{array}$ \\
\hline $\begin{array}{l}\text { Scarpazza } 2013 \\
{[55]}\end{array}$ & $\begin{array}{l}78 \text { patients, assess } \\
\text { NIV success in hyper- } \\
\text { capnic ARF }\end{array}$ & $\begin{array}{c}\text { GCS } 7.2 \pm 1.5 \text { in } \\
\text { non-responsive } \\
\text { patients vs GCS } 9.7 \\
\pm 2.9 \text { in respondive } \\
\text { patients }\end{array}$ & $\begin{array}{l}\text { Single center, pro- } \\
\text { spective, cohort } \\
\text { study }\end{array}$ & $\begin{array}{l}\text { Lower GCS was a } \\
\text { significant indepen- } \\
\text { dent predictor of } \\
\text { NIV failure }\end{array}$ & $\begin{array}{l}\text { Single unit, no IMV } \\
\text { group control }\end{array}$ \\
\hline $\begin{array}{l}\text { van Gemert } 2015 \\
{[56]}\end{array}$ & $\begin{array}{l}50 \text { COPD patients, } \\
\text { assess risk factors in } \\
\text { transition from NIV } \\
\text { to IMV }\end{array}$ & GCS 9-15 & $\begin{array}{l}\text { Retrospective cohort } \\
\text { study }\end{array}$ & $\begin{array}{l}\text { Lower GCS at presen- } \\
\text { tation is } \\
\text { associated with the } \\
\text { transition from NIV to } \\
\text { IMV in COPD } \\
\text { patients with hyper- } \\
\text { capnic ARF }\end{array}$ & $\begin{array}{l}\text { Retrospective study, } \\
\text { small sample size }\end{array}$ \\
\hline Ucgun 2006 [57] & $\begin{array}{l}151 \text { patients, identify } \\
\text { factors affecting } \\
\text { mortality and intuba- } \\
\text { tion in } \\
\text { COPD patients }\end{array}$ & $\begin{array}{c}\text { GCS } 14.1 \pm 1.4 \text { in } \\
\text { nonintubated vs GCS } \\
10.8 \pm 3.4 \text { in intu- } \\
\text { bated }\end{array}$ & $\begin{array}{l}\text { Single center, pro- } \\
\text { spective study }\end{array}$ & $\begin{array}{l}\text { Lower GCS was } \\
\text { associated with intu- } \\
\text { bation }\end{array}$ & $\begin{array}{l}\text { Small sample size, } \\
\text { low rate of NIV ap- } \\
\text { plications, inclusion } \\
\text { of pneumonia and } \\
\text { heart failure leading } \\
\text { to acute exacerbation } \\
\text { of COPD }\end{array}$ \\
\hline Kida 2012 [58] & $\begin{array}{l}42 \text { patients, identify } \\
\text { predictors of NIV suc- } \\
\text { cess in elderly }\end{array}$ & $\begin{array}{l}\text { GCS } 8.9 \pm 2.4 \text { in sur- } \\
\text { vivors vs } 4.0 \pm 1.7 \text { in } \\
\text { non-survivors }\end{array}$ & $\begin{array}{l}\text { Single center, retro- } \\
\text { spective study }\end{array}$ & $\begin{array}{c}\text { GCS }<9 \text { was asso- } \\
\text { ciated with higher } \\
\text { mortality }\end{array}$ & $\begin{array}{l}\text { Retrospective study, } \\
\text { small sample size }\end{array}$ \\
\hline
\end{tabular}

ARF — acute respiratory failure; AVAPS — average volume-assured pressure support; BiPAP — bilevel positive airway pressure; COPD — chronic obstructive pulmonary disease; DNI — do not intubate order; GCS — Glasgow coma scale; ICU — intensive care unit; IMV — invasive mechanical ventilation; IQR — interquartile range; KMS — Kelly-Matthay score; NIV — non-invasive ventilation; RASS — Richmond Agitation-Sedation Scale; TB — tuberculosis 
to respiratory failure of various causes and treated with NIV. At the beginning of ventilatory therapy, arterial $\mathrm{pH}$ was $7.13 \pm 0.06$ and $\mathrm{PaCO}_{2}$ was $99 \pm$ $19 \mathrm{~mm} \mathrm{Hg}$. Improvements in pH, GCS, $\mathrm{PaCO}_{2}$, and $\mathrm{PaO}_{2} / \mathrm{FiO}_{2}$ within the first hour of NIV correlated with NIV success. A high rate of response to NIV was achieved in comatose patients with cardiogenic pulmonary edema, COPD, and obesity. Subjects with acute respiratory distress syndrome (ARDS) and pneumonia had a higher probability of not responding to NIV. These findings support that NIV success may be related to the type and nature of the underlying disease.

Scala et al. [21] conducted a prospective matched case-control study comparing 40 patients with neurological impairment (KMS $\geq 3$ ) secondary to an acute exacerbation of COPD treated with NIV or IMV. In this study, the mean arterial $\mathrm{pH}$ and $\mathrm{PaCO}_{2}$ in NIV patients was $7.22 \pm 0.02$ and $88 \pm 15 \mathrm{~mm} \mathrm{Hg}$. In the control group, these same parameters were $7.22 \pm 0.05$ and $90 \pm 10 \mathrm{~mm} \mathrm{Hg}$. They noted that consciousness improved from a mean of $3.4 \pm 0.6$ to $2.1 \pm 0.8$ points in NIV patients after 2 hours of treatment, and to $1.6 \pm$ 1.0 at 24 hours. Compared to the IMV group, the NIV group showed a shorter duration of mechanical ventilation and a lower complication rate due to fewer cases of nosocomial pneumonia and sepsis despite similar (25\%) in-hospital mortality rates between groups.

In a case control study, Zhu et al. [22] compared a group of 22 exacerbated COPD patients with GCS $<10$ with a control group of 21 subjects with GCS $\geq 10$. They noted similar rates of hospital mortality ( $14 \%$ vs $14 \%, p>0.05)$ and NIV success (73\% vs 68\%, p > 0.05). However, pressure support, NIV time, and hospital length of stay were significantly higher in patients with GCS $<10$.

These studies conclusively demonstrated that many of the consensus-based "absolute" contraindications to NIV should be viewed as "relative", although an increase in failure rates can be expected in the most severe forms of hypercapnic encephalopathy. Additionally, severe complications from NIV are rare. However, most published series have been submitted by teams with extensive experience in ventilatory support, and it is difficult to know whether these results can be extrapolated to other groups with less expertise.

\section{Current evidence against the use of NIV in hypercapnic ARF encephalopathy}

By contrast, there is also evidence that NIV can be harmful in certain settings. Some studies demonstrate high rates of NIV failure in patients with low consciousness levels. In these particular patients who initially receive NIV and then experience NIV failure, there is a subsequent need for them to be intubated in order to undergo IMV, which results in them being more likely to die in the hospital [23, 24]. One possible reason for the increased mortality can be due to an inappropriate initial selection of NIV candidates and/or delay in ETI.

In a study by Confalonieri et al, the risk of NIV failure in a large unselected population admitted to different hospital units with expertise in NIV was assessed. The authors used this data and built two risk charts for NIV failure; one at admission and the other after 2 hours. NIV failure occurred in 236 patients (22.9\%); among those, 142 died (13.7\%). Risk factors for NIV failure included APACHE II score $\geq 29$, GCS $\leq 14, \mathrm{pH}$ $<7.25$, and respiratory rate $\geq 30$ breaths/minute. At admission, in a patient with $\mathrm{pH}<7.25$, APACHE II $\geq 29$ and GCS $\leq 11$, the chart shows a predicted risk of failure $>70 \%$. This risk increases to $90 \%$ if the same parameters are kept after 2 hours [25].

In addition, there is data that suggest additional harm in patients with excessive secretions. Most COPD exacerbations are triggered by pulmonary infections, and exacerbations are usually associated with copious secretions. A previous study has reported that COPD patients with low cough strength were more likely to experience NIV failure (up to 80\%) [26]. In selected scenarios, a reduction in NIV failure may be achieved by initiating early suction of secretions with bronchoscopy performed during NIV by an expert team [27, 28]. In a matched case-control study by Scala et al. [28], bronchoscopy was performed $18.5 \pm 6.9$ minutes after NIV initiation and lasted $7.8 \pm 3.1$ minutes with the removal of $23 \pm 18 \mathrm{~mL}$ of respiratory secretions. In these patients, although both KMS and cough efficiency significantly improved after two hours, NIV still failed in 3 of 15 patients (20\%). Compared to the IMV group, hospital mortality, hospital length of stay, and duration of ventilation were similar to patients in the NIV group.

Finally, a lack of cooperation in agitated patients may limit NIV success [29]. Continuous infusion of a single sedative and analgesic titrated to obtain a "conscious sedation" may decrease patient discomfort and improve gas exchange, with no significant effects on respiratory drive or hemodynamic status [30]. However, larger and more controlled trials are needed to clarify the indications of sedation during NIV. 


\section{Rationale for NIV use in patients with hypoxemic ARF and an altered level of consciousness}

In this section, we will consider non-hypercapnic patients with an altered level of consciousness who have symptoms related to impaired mental function that appeared as a result of hypoxia and sepsis. Hypoxemic non-hypercapnic patients with an altered level of consciousness refers to a syndrome marked by cerebral dysfunction caused by brain hypoxia and ischemia due to hypoxemic ARF. Similarly, septic encephalopathy is an impaired mental status syndrome with a clinical presentation ranging from clouded thinking/consciousness to deep coma as can be seen in patients with systemic inflammation. Pathophysiologic hallmarks are thought to comprise diffuse neuroinflammation, vascular dysfunction, and neurotransmitter imbalances leading to direct cellular neuronal damage, impaired autoregulation, and excitotoxicity [31].

The goal of using NIV is to improve oxygenation, to decrease dyspnea and the work of breathing, and to avoid intubation [32]. It is believed to be beneficial because it recruits collapsed alveoli, increases the functional residual capacity, and decreases intrapulmonary shunt which, as a result, improves respiratory mechanics and gas exchange [33].

Hypoxemic ARF is usually defined as significant hypoxemia $\left(\mathrm{PaO}_{2} / \mathrm{FiO}_{2} \leq 200 \mathrm{~mm} \mathrm{Hg}\right)$ and tachypnea in a patient not diagnosed with COPD [4]. Thus, hypoxemic ARF represents the final result of a large number of different underlying pathologies [34]. Given the variety of the pathophysiology that leads to severe hypoxemia, drawing reasonable conclusions regarding the use of NIV for hypoxemia is associated with significant challenges.

The Berlin definition for ARDS is as follows: mild when $\mathrm{PaO}_{2} / \mathrm{FiO}_{2}$ is $>200$ and $<300 \mathrm{~mm} \mathrm{Hg}$; moderate when $\mathrm{PaO}_{2} / \mathrm{FiO}_{2}$ is $>100$ and $\leq 200 \mathrm{~mm}$ $\mathrm{Hg}$; and as severe when $\mathrm{PaO}_{2} / \mathrm{FiO}_{2} \leq 100 \mathrm{~mm} \mathrm{Hg}$. Positive end-expiratory pressure (PEEP), which can be delivered through NIV, can markedly affect $\mathrm{PaO}_{2} / \mathrm{FiO}_{2}$. Therefore, a minimum level of PEEP (5 $\mathrm{cm} \mathrm{H}_{2} \mathrm{O}$ ) was added to the definition [35].

In the LUNG SAFE Study, 2813 patients with ARDS were managed with NIV or IMV irrespective of the severity category. In this study, NIV failure occurred in $37.5 \%$ of patients with ARDS and in almost half of patients with moderate and severe ARDS. NIV was associated with a worse adjusted ICU mortality than IMV in patients with a $\mathrm{PaO}_{2} / \mathrm{FiO}_{2}<150 \mathrm{~mm} \mathrm{Hg}$. However, there was no difference in hospital mortality [36].
Additionally, a new concept of patient self-inflicted lung injury can arise as spontaneous vigorous effort in non-intubated patients has been shown to worsen lung injury in moderate to severe ARDS. Higher EPAP through NIV can reduce the amount of atelectasis in the lung, decrease force generated by spontaneous effort, and often improves gas exchange. However, even in volume-controlled NIV mode, spontaneous effort can deteriorate lung injury by increasing local lung stress and overdistension [37].

As such, the use of NIV in patients with severe hypoxemic ARF is controversial [6, 38]. Most of the published literature has focused on common hypoxemic clinical conditions such as acute pulmonary edema and pneumonia [39]. Other investigations have focused on the use of NIV in severely hypoxemic patients due to ARDS $[36,40]$.

\section{Current evidence for the use of NIV in hypoxemic ARF in patients with an altered level of consciousness}

We reviewed published studies designed to assess the use of NIV as a first-line intervention in hypoxemic ARF to avoid ETI. However, the majority of studies excluded patients with altered levels of consciousness. Studies on altered mental status due to primitive neurological diseases (e.g. stroke) or metabolic/toxic causes were not included (Figure 2, Table 2).

Only one study compared NIV efficacy in hypoxemic ARF in patients with an altered level of consciousness (GCS 9-14) versus patients with full awareness [41]. Patients were divided into two groups according to the presence (66 patients) or absence (82 patients) of encephalopathy. Patients with encephalopathy were older (median of $72 \mathrm{vs}$ 78 years, $p=0.02$ ), had a higher APACHE II score (18 vs $19, \mathrm{p}=0.02$ ), and received a higher level of IPAP. With the caveat of being a retrospective study with important baseline imbalances, there were no significant differences between groups in rates of NIV failure $(24 \%$ vs $30 \%, \mathrm{p}=0.4)$ and in in-hospital mortality ( $13 \%$ vs $16 \%, \mathrm{p}=0.3$ ).

Data from other studies must be cautiously taken into account as they did not exclude patients from their studies based simply on a certain level of awareness. Changes to the level of consciousness were not primary or secondary endpoints.

In a randomized clinical trial, Ferrer et al. [42] compared the efficacy of NIV versus the Venturi mask with $\mathrm{FiO}_{2}$ of $50 \%$ based on survival 


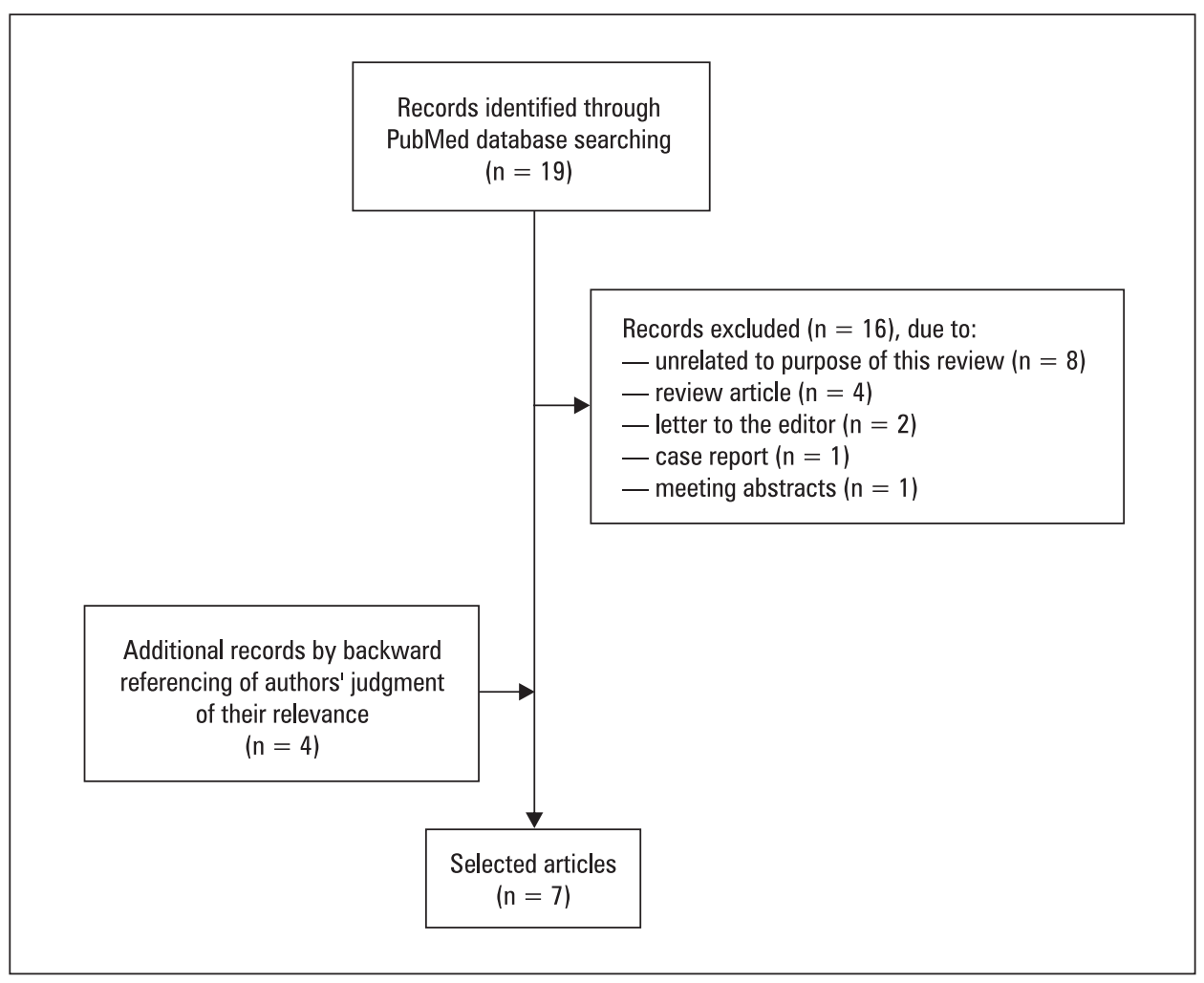

Figure 2. Flowchart of the study selection process for using non-invasive ventilation in hypoxemic acute respiratory failure in patients with an altered level of consciousness

and avoidance of ETI in 105 patients with GCS 12-15 and hypoxemic ARF. After multivariate analysis, NIV was independently associated with a decreased risk of ETI (OR 0.20, p = 0.003) and 90-day mortality (OR 0.39, $\mathrm{p}=0.017$ ).

In a study enrolling cardiogenic pulmonary edema patients with hypoxemic ARF who had a mildly altered level of consciousness (GCS 8-15), CPAP significantly improved 48-hour mortality ( $7 \%$ vs $24 \%, \mathrm{p}=0.017)$ and reduced the need for intubation ( $9 \%$ vs $30 \%, \mathrm{p}=0.001$ ). However, there was no improvement in in-hospital mortality compared to that of standard medical care [43].

Patel et al. conducted a study of ARDS patients with GCS 8-15 randomized to treatment with NIV delivered by helmet or face mask. Patients in the helmet (vs face mask) group showed a lower need for ETI (18.2\% vs 61.5\%, p < 0.001) and an improved survival rate at 90 days from randomization (34.1\% vs $56.4 \%, \mathrm{p}=0.02$ ) [44]. That being said, the helmet group had significantly higher EPAP and lower pressure support results compared to the face mask group which may have influenced the final results.

Hilbert et al. published a study comparing the use of NIV to standard treatment with sup- plemental oxygen to treat immunosuppressed patients with hypoxemic ARF, including those with mildly altered levels of consciousness (GCS 9-15). This study showed that NIV can obviate the need for ETI in this population (46\% vs $77 \%$, $\mathrm{p}=0.03$ ) and diminish in-hospital mortality rates (50\% vs $81 \%, p=0.02)$ [45].

In summary, the current literature is insufficient to address the efficacy of NIV compared to other treatments in patients with hypoxemic non-hypercapnic ARF who also have an altered level of consciousness.

\section{Current evidence against the use of NIV in hypoxemic ARF in patients with an altered level of consciousness}

Delayed intubation in patients undergoing trials of NIV can lead to increased mortality [46, 47]. A previous study has reported a useful score (HACOR score) to predict NIV failure in patients with de novo hypoxemic ARF [48]. In this score, consciousness accounts for the highest weight among all risk factors for NIV failure. Patients with higher HACOR scores were more likely to experience NIV failure. Regarding consciousness, one assigns a HACOR score of 0 for GCS 15, 2 for 
Table 2. Current evidence for using NIV in hypoxemic ARF in patients with an altered level of consciousness

\begin{tabular}{|c|c|c|c|c|c|}
\hline Author, year & $\begin{array}{l}\text { Patients and aim of } \\
\text { the study }\end{array}$ & $\begin{array}{c}\text { Level of } \\
\text { consciousness }\end{array}$ & Type of study & Results & Limitations \\
\hline Kogo 2018 [41] & $\begin{array}{l}148 \text { patients, NIV effi- } \\
\text { cacy in mildly altered } \\
\text { consciousness }\end{array}$ & GCS 9-14 vs GCS 15 & Retrospective study & $\begin{array}{l}\text { No significant diffe- } \\
\text { rences in NIV failure } \\
\text { and in-hospital mor- } \\
\text { tality }\end{array}$ & Retrospective study \\
\hline Ferrer 2003 [42] & $\begin{array}{l}105 \text { with severe ARF, } \\
\text { NIV vs oxygen }\end{array}$ & GCS $12-15$ & $\begin{array}{l}\text { Prospective, rando- } \\
\text { mized controlled. } \\
\text { Compares oxygen } \\
\text { with NIV }\end{array}$ & $\begin{array}{l}\text { NIV improves oxyge- } \\
\text { nation, mortality, and } \\
\text { decreases intubation } \\
\text { rates }\end{array}$ & $\begin{array}{c}\text { Difficulty for a correct } \\
\text { blinding, relative } \\
\text { heterogeneity of } \\
\text { patients }\end{array}$ \\
\hline L'Her 2004 [43] & $\begin{array}{l}89 \text { patients with } \\
\text { cardiogenic pulmo- } \\
\text { nary edema, CPAP vs } \\
\text { standard treatment }\end{array}$ & GCS 8-15 & $\begin{array}{l}\text { Prospective, randomi- } \\
\text { zed, concealed, } \\
\text { and unblinded study }\end{array}$ & $\begin{array}{l}\text { Reduction in early } 48 \\
\text { h-mortality and ETI }\end{array}$ & Blinding impossible \\
\hline Patel 2016 [44] & $\begin{array}{c}83 \text { patients with } \\
\text { ARDS, helmet } v s \text { face } \\
\text { mask }\end{array}$ & GCS 8-15 & $\begin{array}{l}\text { Single-center rando- } \\
\text { mized clinical trial }\end{array}$ & $\begin{array}{l}\text { Reduction of intuba- } \\
\text { tion rates and } 90 \text {-day } \\
\text { mortality with helmet } \\
\text { NIV }\end{array}$ & Blinding impossible \\
\hline Hilbert 2001 [45] & $\begin{array}{l}52 \text { immunosuppres- } \\
\text { sed patients, NIV vs } \\
\text { standard treatment }\end{array}$ & GCS -15 & $\begin{array}{l}\text { Prospective, randomi- } \\
\text { zed trial }\end{array}$ & $\begin{array}{l}\text { Reduction in ETI, } \\
\text { serious complications } \\
\text { and mortality }\end{array}$ & $\begin{array}{l}\text { Blinding impossible, } \\
\text { single unit }\end{array}$ \\
\hline Duan 2017 [48] & $\begin{array}{l}358 \text { patients in the } \\
\text { validation cohort, } \\
\text { develop a scale to } \\
\text { predict NIV failure in } \\
\text { hypoxemic ARF }\end{array}$ & $\begin{array}{c}\text { GCS in NIV success } \\
14.8 \pm 0.6 \text { vs } 14.3 \pm \\
1.6 \text { in the NIV failure } \\
\text { group }\end{array}$ & $\begin{array}{l}\text { Prospective observa- } \\
\text { tional study }\end{array}$ & $\begin{array}{l}\text { NIV failure was asso- } \\
\text { ciated with } \\
\text { lower GCS }\end{array}$ & Observational study \\
\hline Thille 2013 [49] & $\begin{array}{l}113 \text { patients, assess } \\
\text { rates and predictive } \\
\text { factors of NIV failure }\end{array}$ & $\begin{array}{c}\text { GCS in NIV success } \\
14.9 \pm 0.5 \text { vs } 14.6 \pm \\
1.2 \text { in the NIV failure } \\
\text { group }\end{array}$ & $\begin{array}{l}\text { Observational cohort } \\
\text { study }\end{array}$ & $\begin{array}{l}\text { NIV failure was asso- } \\
\text { ciated with } \\
\text { lower GCS }\end{array}$ & $\begin{array}{l}\text { Single unit with lon- } \\
\text { gstanding experience } \\
\text { in the use of NIV }\end{array}$ \\
\hline
\end{tabular}

ARDS — acute respiratory distress syndrome; ARF — acute respiratory failure; CPAP — continuous positive airway pressure; ETI — endotracheal intubation; GCS — Glasgow coma scale; NIV — non-invasive ventilation

GCS 13-14, 5 for GCS 11-12, and 10 for GCS $\leq$ 10. In this study, in patients with a HACOR score $>5$, the risk for NIV failure reached up to $80 \%$. Thus, the use of NIV in patients with low levels of consciousness must be done cautiously, especially in those with GCS $\leq 10$.

In an observational cohort study, Thille et al. [49] assessed the rates and predictive factors of NIV failure in patients admitted to the ICU for hypoxemic ARF. Among 113 patients receiving NIV, 82 had ARDS and 31 had non-ARDS. Intubation rates significantly differed between ARDS and non-ARDS patients ( $61 \%$ vs $35 \%, \mathrm{p}=0.015)$ according to the clinical severity of ARDS. NIV failure was associated with active cancer, shock, moderate/severe ARDS, lower EPAP at NIV initiation, and lower GCS ( $p=0.018)$.

In fact, the latest ERS/ATS clinical practice guidelines for NIV do not offer a recommendation about NIV use for de novo hypoxemic ARF [4]. This is justified, firstly, by the fact that as soon as NIV is ceased, the positive effects previously gained in terms of alveolar recruitment and oxygenation are lost. Secondly, during NIV, tidal volume results from the pressures given by the ventilator coupled with the respiratory muscle pressure generated by the patient's respiratory drive. Due to this mechanism, tidal volume is often high and may trigger ventilator-induced lung injury which contrasts with the intended lung protective ventilation strategies (low tidal volume of $6 \mathrm{~mL} / \mathrm{kg}$ of predicted body weight) [32]. Finally, in a randomized controlled trial, the use of high-flow nasal cannula therapy has shown benefit in patient survival when compared with NIV and standard oxygen therapy in the treatment of hypoxemic ARF [50].

\section{Conclusion}

The overall analysis of the studies reviewed support the use of NIV as an adjunctive therapy in patients with hypercapnic encephalopathy because it decreases complication rates, the 
Table 3. Advantages and disadvantages for using NIV over IMV in hypercapnic ARF encephalopathy

\begin{tabular}{lc}
\hline Advantages & Disadvantages \\
\hline Less complication rates & Benefits decrease with lower levels of consciousness \\
Less cost & Benefits more significant in acute pulmonary edema, COPD, \\
Less hospital and ICU length of stay & and obesity rather than ARDS or pneumonia \\
Less mortality & \\
\hline
\end{tabular}

ARDS — acute respiratory distress syndrome; COPD — chronic obstructive pulmonary disease; ICU — intensive care unit

Table 4. Advantages and disadvantages for using NIV over IMV in hypoxemic ARF in patients with an altered level of consciousness

\begin{tabular}{lc}
\hline Advantages & Disadvantages \\
\hline Less complication rates & NIV failure associated with active cancer, shock, moderate/severe ARDS \\
Less cost & Higher risk of NIV failure when GCS $\leq 10$ \\
\hline
\end{tabular}

ARDS — acute respiratory distress syndrome; EPAP — expiratory positive airway pressure; GCS — Glasgow coma scale; NIV — non-invasive ventilation

need for ETI, hospital length of stay, and mortality rate when compared to IMV. Patients with hypercapnic ARF and impaired consciousness can be treated with NIV, however, these results appear to be more relevant to specific patient populations including those with acute pulmonary edema, COPD, and obesity rather than conditions such as ARDS or pneumonia. Close monitoring is also mandatory as improvements in blood gas percentages within the first hours correlate with NIV success (Table 3).

Data regarding NIV effectiveness in hypoxemic ARF patients with an altered level of consciousness are more controversial given the heterogeneity of the studies identified and the fact that many studies excluded patients with alterations in mental status. Based on the examined studies, there is no evidence to either support or reject the routine use of NIV in patients with hypoxemic altered levels of consciousness due to ARF. However, NIV failure seems to increase with declining levels of consciousness. A multicenter, randomized, and controlled study trial is needed to clarify whether a benefit of NIV exists compared to other supportive treatments with regard to clinically important outcomes such as intubation rate, mortality, hospital/ICU length of stay, and other patient-centered outcome measures (Table 4).

In all cases, increased clinical experience in administering NIV, patient tolerance, and selection of the most appropriate interfaces are important considerations. The clinical status of the patient must be carefully monitored during NIV application. Clinicians must ensure that the use of NIV does not delay the need for ETI in patients who are deteriorating during NIV treatment. Proper patient monitoring is critical to ensure safe NIV initiation and titration. Skills in NIV application and limiting its use to highly monitored clinical settings are critical factors to consider to ensure optimal use of NIV and patient safety.

\section{Conflict of interest}

None declared.

\section{References:}

1. Keenan SP, Sinuff T, Cook DJ, et al. Which patients with acute exacerbation of chronic obstructive pulmonary disease benefit from noninvasive positive-pressure ventilation? A systematic review of the literature. Ann Intern Med. 2003; 138(11): 861-870, doi: 10.7326/0003-4819-138-11-200306030-00007. indexed in Pubmed: 12779296.

2. Lightowler JV, Wedzicha JA, Elliott MW, et al. Non-invasive positive pressure ventilation to treat respiratory failure resulting from exacerbations of chronic obstructive pulmonary disease: Cochrane systematic review and meta-analysis. BMJ. 2003; 326(7382): 185, doi: 10.1136/bmj.326.7382.185, indexed in Pubmed: 12543832.

3. Lopez-Campos JL, Garcia Polo C, Leon Jimenez A, et al. Staff training influence on non-invasive ventilation outcome for acute hypercapnic respiratory failure. Monaldi Arch Chest Dis. 2006; 65(3): 145-151, doi: 10.4081/monaldi.2006.560, indexed in Pubmed: 17220104.

4. Rochwerg B, Brochard L, Elliott MW, et al. Official ERS/ ATS clinical practice guidelines: noninvasive ventilation for acute respiratory failure. Eur Respir J. 2017; 50(2), doi: 10.1183/13993003.02426-2016, indexed in Pubmed: 28860265.

5. Chawla R, Dixit SB, Zirpe KG, et al. ISCCM guidelines for the use of non-invasive ventilation in acute respiratory failure in adult icus. Indian J Crit Care Med. 2020; 24(Suppl 1): S61-S81, 
doi: 10.5005/jp-journals-10071-G23186, indexed in Pubmed: 32205957.

6. Antonelli M, Conti G, Rocco M, et al. A comparison of noninvasive positive-pressure ventilation and conventional mechanical ventilation in patients with acute respiratory failure. N Engl J Med. 1998; 339(7): 429-435, doi: 10.1056/ NEJM199808133390703, indexed in Pubmed: $\underline{9700176 .}$

7. Mehta S, Hill NS. Noninvasive ventilation. Am J Respir Crit Care Med. 2001; 163(2): 540-577, doi: 10.1164/ajrccm.163.2.9906116, indexed in Pubmed: 11179136.

8. Evans TW. International Consensus Conferences in icine: non -invasive positive pressure ventilation in acute respiratory failure. Organised jointly by the American Thoracic Society, the European Respiratory Society, the European Society of icine, and the Societe de Reanimation de Langue Francaise, and approved by the ATS Board of Directors, December 2000. Intensive Care Med. 2001; 27(1): 166-178.

9. Teasdale G, Jennett B. Assessment of coma and impaired consciousness. A practical scale. Lancet. 1974; 2(7872): 81-84, doi: 10.1016/s0140-6736(74)91639-0, indexed in Pubmed: 4136544.

10. Kelly BJ, Matthay MA. Prevalence and severity of neurologic dysfunction in critically ill patients. Influence on need for continued mechanical ventilation. Chest. 1993; 104(6): 1818-1824, doi: 10.1378/chest.104.6.1818, indexed in Pubmed: 8252971 .

11. Scala R. Hypercapnic encephalopathy syndrome: a new frontier for non-invasive ventilation? Respir Med. 2011; 105(8): 1109-1117, doi: 10.1016/j.rmed.2011.02.004, indexed in Pubmed: 21354774 .

12. Honrubia T, García López FJ, Franco N, et al. Noninvasive vs conventional mechanical ventilation in acute respiratory failure: a multicenter, randomized controlled trial. Chest. 2005; 128(6): 3916-3924, doi: 10.1378/chest.128.6.3916, indexed in Pubmed: 16354864 .

13. Gay PC. Complications of noninvasive ventilation in acute care. Respir Care. 2009; 54(2): 246--258.

14. Bitnar P, Stovicek J, Andel R, et al. Leg raise increases pressure in lower and upper esophageal sphincter among patients with gastroesophageal reflux disease. J Bodyw Mov Ther. 2016; 20(3): 518-524, doi: 10.1016/i.jbmt.2015.12.002, indexed in Pubmed: 27634073 .

15. Pandolfino JE, Gawron AJ. Achalasia: a systematic review. JAMA. 2015; 313(18): 1841-1852, doi: 10.1001/ jama.2015.2996, indexed in Pubmed: 25965233.

16. Lemyze M, De Palleja G, Guiot A, et al. Outcome of frail do-not-intubate subjects with end-stage chronic respiratory failure and their opinion of noninvasive ventilation to reverse hypercapnic coma. Respir Care. 2019; 64(9): 1023-1030, doi: 10.4187/respcare.06346, indexed in Pubmed: 30890633.

17. Mas A, Masip J. Noninvasive ventilation in acute respiratory failure. Int J Chron Obstruct Pulmon Dis. 2014; 9: 837-852, doi: 10.2147/COPD.S42664, indexed in Pubmed: 25143721.

18. Corrado A, De Paola E, Gorini M, et al. Intermittent negative pressure ventilation in the treatment of hypoxic hypercapnic coma in chronic respiratory insufficiency. Thorax. 1996; 51(11): 1077-1082, doi: 10.1136/thx.51.11.1077, indexed in Pubmed: 8958888.

19. Briones Claudett KH, Briones Claudett MH, Chung Sang Wong MA, et al. Noninvasive mechanical ventilation in patients with chronic obstructive pulmonary disease and severe hypercapnic neurological deterioration in the emergency room. Eur J Emerg Med. 2008; 15(3): 127-133, doi: 10.1097| MEJ.0b013e3282f08d08, indexed in Pubmed: 18460951.

20. Díaz GG, Alcaraz AC, Talavera JC, et al. Noninvasive positive -pressure ventilation to treat hypercapnic coma secondary to respiratory failure. Chest. 2005; 127(3): 952-960, doi: 10.1378/ chest.127.3.952, indexed in Pubmed: 15764781.

21. Scala R, Nava S, Conti G, et al. Noninvasive versus conventional ventilation to treat hypercapnic encephalopathy in chronic obstructive pulmonary disease. Intensive Care Med. 2007; 33(12): 2101-2108, doi: 10.1007/s00134-007-0837-2, indexed in Pubmed: 17874232.

22. Zhu Gf, Zhang W, Zong H, et al. Effectiveness and safety of noninvasive positive-pressure ventilation for severe hyper- capnic encephalopathy due to acute exacerbation of chronic obstructive pulmonary disease: a prospective case-control study. Chin Med J (Engl). 2007; 120(24): 2204-2209, indexed in Pubmed: 18167203.

23. Chandra D, Stamm JA, Taylor B, et al. Outcomes of noninvasive ventilation for acute exacerbations of chronic obstructive pulmonary disease in the United States, 1998-2008. Am J Respir Crit Care Med. 2012; 185(2): 152-159, doi: 10.1164/ rccm.201106-1094OC, indexed in Pubmed: 22016446.

24. Stefan MS, Nathanson BH, Higgins TL, et al. Comparative effectiveness of noninvasive and invasive ventilation in critically ill patients with acute exacerbation of chronic obstructive pulmonary disease. Crit Care Med. 2015; 43(7): 1386-1394, doi: 10.1097/CCM.0000000000000945, indexed in Pubmed: 25768682.

25. Confalonieri M, Garuti G, Cattaruzza MS, et al. Italian noninvasive positive pressure ventilation (NPPV) study group. A chart of failure risk for noninvasive ventilation in patients with COPD exacerbation. Eur Respir J. 2005; 25(2): 348-355, doi: 10.1183/09031936.05.00085304, indexed in Pubmed: 15684302.

26. Fan L, Zhao Q, Liu Y, et al. Semiquantitative cough strength score and associated outcomes in noninvasive positive pressure ventilation patients with acute exacerbation of chronic obstructive pulmonary disease. Respir Med. 2014; 108(12): 1801-1807, doi: 10.1016/j.rmed.2014.10.001, indexed in Pubmed: 25459451.

27. Wang J, Cui Z, Liu S, et al. Early use of noninvasive techniques for clearing respiratory secretions during noninvasive positive-pressure ventilation in patients with acute exacerbation of chronic obstructive pulmonary disease and hypercapnic encephalopathy: A prospective cohort study. Medicine (Baltimore). 2017; 96(12): e6371, doi: 10.1097/MD.0000000000006371, indexed in Pubmed: 28328824.

28. Scala R, Naldi M, Maccari U. Early fiberoptic bronchoscopy during non-invasive ventilation in patients with decompensated chronic obstructive pulmonary disease due to community-acquired-pneumonia. Crit Care. 2010; 14(2): R80, doi: 10.1186/cc8993, indexed in Pubmed: 20429929.

29. Scala R. Non-invasive ventilation in acute respiratory failure with altered consciousness syndrome: a bargain or an hazard? Minerva Anestesiol. 2013; 79(11): 1291-1299, indexed in Pubmed: 23719655 .

30. Huang Z, Chen Ys, Yang Zl, et al. Dexmedetomidine versus midazolam for the sedation of patients with non-invasive ventilation failure. Intern Med. 2012; 51(17): 2299-2305, doi: 10.2169/internalmedicine.51.7810, indexed in Pubmed: 22975538 .

31. Tauber SC, Eiffert H, Brück W, et al. Fungal encephalitis in human autopsy cases is associated with extensive neuronal damage but only minimal repair. Neuropathol Appl Neurobiol. 2014; 40(5): 610-627, doi: 10.1111/nan.12044, indexed in Pubmed: 23517274.

32. Scala R, Pisani L. Noninvasive ventilation in acute respiratory failure: which recipe for success? Eur Respir Rev. 2018; 27(149), doi: 10.1183/16000617.0029-2018, indexed in Pubmed: 29997247.

33. Bello G, De Pascale G, Antonelli M, et al. Noninvasive ventilation for the immunocompromised patient: always appropriate? Curr Opin Crit Care. 2012; 18(1): 54-60, doi: 10.1097/ MCC.0b013e32834e7c21, indexed in Pubmed: 22143051.

34. Narendra DK, Hess DR, Sessler CN, et al. Update in management of severe hypoxemic respiratory failure. Chest. 2017; 152(4): 867-879, doi: 10.1016/i.chest.2017.06.039, indexed in Pubmed: 28716645.

35. Ranieri VM, Rubenfeld GD, Thompson BT, et al. ARDS Definition Task Force. Acute respiratory distress syndrome: the Berlin Definition. JAMA. 2012; 307(23): 2526-2533, doi: 10.1001/jama.2012.5669, indexed in Pubmed: 22797452.

36. Bellani G, Laffey JG, Pham T, et al. LUNG SAFE Investigators, ESICM Trials Group. Noninvasive ventilation of patients with acute respiratory distress syndrome. Insights from the LUNG SAFE study. Am J Respir Crit Care Med. 2017; 195(1): 67-77, doi: 10.1164/rccm.201606-13060C, indexed in Pubmed: 27753501. 
37. Yoshida T, Grieco DL, Brochard L, et al. Patient self-inflicted lung injury and positive end-expiratory pressure for safe spontaneous breathing. Curr Opin Crit Care. 2020; 26(1): 59-65, doi: 10.1097/MCC.0000000000000691, indexed in Pubmed: 31815775 .

38. Xu XP, Zhang XC, Hu SL, et al. Noninvasive ventilation in acute hypoxemic nonhypercapnic respiratory failure: a systematic review and meta-analysis. Crit Care Med. 2017; 45(7): e727-e733, doi: 10.1097/CCM.0000000000002361, indexed in Pubmed: 28441237.

39. Antonelli M, Conti G, Moro ML, et al. Predictors of failure of noninvasive positive pressure ventilation in patients with acute hypoxemic respiratory failure: a multi-center study. Intensive Care Med. 2001; 27(11): 1718-1728, doi: $10.1007 /$ s00134-001-1114-4, indexed in Pubmed: 11810114.

40. Bernard GR, Artigas A, Brigham KL, et al. Report of the American-European consensus conference on ARDS: definitions, mechanisms, relevant outcomes and clinical trial coordination. The Consensus Committee. Intensive Care Med. 1994; 20(3): 225232, doi: 10.1007/BF01704707, indexed in Pubmed: 8014293.

41. Kogo M, Nagata K, Morimoto T, et al. What is the impact of mildly altered consciousness on acute hypoxemic respiratory failure with non-invasive ventilation? Intern Med. 2018; 57(12): 1689-1695, doi: 10.2169/internalmedicine.9355-17. indexed in Pubmed: 29434147.

42. Ferrer M, Esquinas A, Leon M, et al. Noninvasive ventilation in severe hypoxemic respiratory failure: a randomized clinical trial. Am J Respir Crit Care Med. 2003; 168(12): 1438-1444, doi: 10.1164/rccm.200301-072OC, indexed in Pubmed: 14500259.

43. L'Her E, Duquesne F, Girou E, et al. Noninvasive continuous positive airway pressure in elderly cardiogenic pulmonary edema patients. Intensive Care Med. 2004; 30(5): 882-888, doi: 10.1007/s00134-004-2183-y, indexed in Pubmed: 14991092.

44. Patel BK, Wolfe KS, Pohlman AS, et al. Effect of noninvasive ventilation delivered by helmet vs face mask on the rate of endotracheal intubation in patients with acute respiratory distress syndrome: a randomized clinical trial. JAMA. 2016; 315(22): 2435-2441, doi: 10.1001/jama.2016.6338, indexed in Pubmed: 27179847.

45. Hilbert G, Gruson D, Vargas F, et al. Noninvasive ventilation in immunosuppressed patients with pulmonary infiltrates, fever, and acute respiratory failure. N Engl J Med. 2001; 344(7): 481-487, doi: 10.1056/NEJM200102153440703, indexed in Pubmed: 11172189 .

46. Esteban A, Frutos-Vivar F, Ferguson ND, et al. Noninvasive positive-pressure ventilation for respiratory failure after extubation. N Engl J Med. 2004; 350(24): 2452-2460, doi: 10.1056/ NEJMoa032736, indexed in Pubmed: 15190137.

47. Kikuchi T, Toba S, Sekiguchi Y, et al. Protocol-based noninvasive positive pressure ventilation for acute respiratory failure. J Anesth. 2011; 25(1): 42-49, doi: 10.1007/s00540-010-1051-x, indexed in Pubmed: 21153036.
48. Duan J, Han X, Bai L, et al. Assessment of heart rate, acidosis, consciousness, oxygenation, and respiratory rate to predict noninvasive ventilation failure in hypoxemic patients. Intensive Care Med. 2017; 43(2): 192-199, doi: 10.1007/s00134-0164601-3, indexed in Pubmed: 27812731.

49. Thille AW, Contou D, Fragnoli C, et al. Non-invasive ventilation for acute hypoxemic respiratory failure: intubation rate and risk factors. Crit Care. 2013; 17(6): R269, doi: 10.1186/ cc13103, indexed in Pubmed: 24215648.

50. Coudroy R, Frat JP, Ehrmann S, et al. REVA Network, REVA network, FLORALI Study Group, REVA Network. High-flow oxygen through nasal cannula in acute hypoxemic respiratory failure. N Engl J Med. 2015; 372(23): 2185-2196, doi: 10.1056/ NEJMoa1503326, indexed in Pubmed: 25981908.

51. Contou D, Fragnoli C, Córdoba-Izquierdo A, et al. Noninvasive ventilation for acute hypercapnic respiratory failure: intubation rate in an experienced unit. Respir Care. 2013; 58(12): 2045-2052, doi: 10.4187/respcare.02456, indexed in Pubmed: 23737546 .

52. Briones Claudett KH, Briones Claudett M, Chung Sang Wong $\mathrm{M}$, et al. Noninvasive mechanical ventilation with average volume assured pressure support (AVAPS) in patients with chronic obstructive pulmonary disease and hypercapnic encephalopathy. BMC Pulm Med. 2013; 13: 12, doi: 10.1186/14712466-13-12, indexed in Pubmed: 23497021.

53. Scala R, Naldi M, Archinucci I, et al. Noninvasive positive pressure ventilation in patients with acute exacerbations of COPD and varying levels of consciousness. Chest. 2005; 128(3): 1657-1666, doi: 10.1378/chest.128.3.1657, indexed in Pubmed: 16162772.

54. Jatoi S, Akhter S, Rizvi N, et al. Standard factors predicting success of Non-invasive ventilation are useful in treating Patients with POST Tuberculosis sequel. J Pak Med Assoc. 2019; 69(8): 1146-1149, indexed in Pubmed: 31431769.

55. Scarpazza P, Incorvaia C, Melacini C, et al. Shrinking the room for invasive ventilation in hypercapnic respiratory failure. Int J Chron Obstruct Pulmon Dis. 2013; 8: 135-137, doi: 10.2147/ COPD.S41374, indexed in Pubmed: 23516004.

56. van Gemert JP, Brijker F, van Gemert JP, et al. Intubation after noninvasive ventilation failure in chronic obstructive pulmonary disease: associated factors at emergency department presentation. Eur J Emerg Med. 2015; 22(1): 49-54, doi: 10.1097/ MEJ.0000000000000141, indexed in Pubmed: 24637440.

57. Ucgun I, Metintas M, Moral H, et al. Predictors of hospital outcome and intubation in COPD patients admitted to the respiratory ICU for acute hypercapnic respiratory failure. Respir Med. 2006; 100(1): 66-74, doi: 10.1016/i.rmed.2005.04.005, indexed in Pubmed: 15890508.

58. Kida Y, Minakata Y, Yamada Y, et al. Efficacy of noninvasive positive pressure ventilation in elderly patients with acute hypercapnic respiratory failure. Respiration. 2012; 83(5): 377382, doi: 10.1159/000328399, indexed in Pubmed: 21734354. 